\title{
Abrangências do conhecimento através da mente humana
}

\section{Raíla Suelen Pereira Viana ${ }^{1}$}

RESUMO: O presente trabalho tem o foco em analisar quais os benefícios que a pesquisa de Locke trouxe para o melhor entendimento sobre o conhecimento humano e de quais as formas de aprendizado que o ser humano estabelece através de suas crenças, modo de vida e as noções do que é certo a seguir. Essa foi uma das questões propostas pelo filósofo Locke (1632-1704), e foi nessa busca do conhecimento humano que ele deixou uma rica pesquisa para a história.

Palavras-Chave: Conhecimento; Mente Humana; Crenças.

A presente pesquisa teve como objetivo entender os parâmetros do conhecimento pela visão do filósofo em questão, que com seus princípios trouxe um novo jeito de perceber como a mudança de comportamento do ser humano se dá através de seus atos .

O filósofo que nos mostra amplo conteúdo sobre o assunto chama-se John Locke (16321704), também é considerado um dos fundadores do empirismo inglês. Mesmo que sua principal contribuição ao pensamento moderno tenha sido talvez no campo da filosofia política, Locke desenvolveu importantes teorias sobre o conhecimento humano.

\section{A filosofia e estudo do conhecimento humano}

A mente humana é algo bastante estudada e uma das preocupações de vários filósofos é a de saber onde é fundado o conhecimento da mente humana? Desde de criança, já temos noções do que se passa ao redor e com essa percepção conseguimos nos diferenciar de outras pessoas. No estudo percebido através de leituras bibliográficas, percebemos que a grande proeza do homem foi sempre a de evoluir, já que era preciso muito esforço para realização de todas as

\footnotetext{
${ }^{1}$ Graduanda em Filosofia pela Cead - UFPI
} 
tarefas do dia-a-dia, como se alimentar e se proteger dos perigos encontrados. E era os conflitos e dilemas mais relatados por grandes autores como Locke que abaixo nos mostra esse pensamento através de suas teses:

Rejeitava a doutrina das ideias e afirmava que todas as nossas ideias tinham origem no que era percebido pelos sentidos. A filosofia da mente de Locke é frequentemente citada como a origem das concepções modernas de identidade e do "Eu". O conceito de identidade pessoal, seus conceitos e questionamentos figuraram com destaque na obra de filósofos posteriores, como Hume, e Kant. Locke foi o primeiro a definir o "si mesmo" através de uma continuidade de consciência (Brandão, 2006, p. 5).

O filósofo, com suas grandes teorias, nos mostra como o ser humano pode ser contraditório em tudo que faz, desde um pensamento de uma nova concepção ou até mesmo de gosto pessoal que através do tempo muda constantemente. Segundo Locke, são claros os limites do entendimento do homem, sem com isso menosprezar a sua importância e utilidade, particularmente à conduta do ser humano. Em clara oposição à Descartes, para quem a essência do sujeito consciente (substância pensante) é o pensamento, Locke, enfatiza a observação, contudo essa é:

A limitação fundamental de Locke no terreno do conhecimento [que] radicava, segundo Kant, em que o pensador inglês, [...] [tinha] herdada do filosofo Aristóteles (RODRIGUEZ, 2010 p. 10 - grifos nossos).

O filósofo Locke também teve dificuldades em suas pesquisas, já que seria preciso muitos esforços para compreender a mente humana, ele, em suas pesquisas sobre o conhecimento teve Aristóteles como base e inspiração. Para continuar sua pesquisa, acabou nos deixando um bom relato, mas que ainda é preciso de muito mais estudos para entender o ser humano e a sociedade em si.

\subsection{Acerca das Ideias em Geral e das suas origens}

Locke inicia a obra destacando que a ideia é objeto imediato da percepção, tanto do que o homem vê em sua cultura desde os ensinamentos de seus pais, quanto o que pode ter grande efeito na formação de sua personalidade e assim transformando seus conhecimentos. Supondo que as ideias existem de fato na mente humana, a questão que se coloca é acerca das origens das mesmas. Ora tendo sido descartado o caráter inato daquelas no primeiro Ensaio sobre o entendimento bumano. (Locke, 1690) 
A filosofia de Locke defendia e demostrava sua opinião e tese através de ideias que ele tinha como base do conhecimento humano e as dividias em três tipos: qualidades primárias (solidez, extensão, forma, mobilidade), qualidades secundárias (cheiros, sabores, cores), poderes passivos (provenientes da capacidade que têm as coisas de produzirem em nós ideias). É assim que se forma o homem, através de experiências que vão sendo vivenciadas e escolhas que irá fazer ao longo de sua vida.

Locke foi um grande defensor da educação, e nesse livro I é possível ver como ele rejeitava toda a noção de inferioridade de outros povos, uma vez que ele crê que um indígena da América poderia muito bem se tornar um teólogo ou matemático, se a ele fosse dada a condição de ter uma educação idêntica à de um inglês. Nenhuma criança nasce com um pensamento pronto sobre o que tem gosto amargo ou doce, ou sobre questões matemáticas e morais. Exemplo dado por Locke: nenhuma criança nasce amando ou respeitando os pais. Tudo isso é adquirido na nossa infância através da educação, e não por alguma ideia inata (PIMENTA, 2013, p. 12).

Através deste pensamento percebemos o grande foco que o filósofo dava pela ideia de que é através dos ensinamentos que podemos construir um Eu do futuro, com opiniões e participação na sociedade e na luta por seus ideais. E assim, por meios do que foi criado em seus dias, essa criança possa ser um grande contribuidor da sociedade. Mas, é também a partir dessas fontes de conhecimento que as crianças, as vezes, já são ensinadas a terem preconceitos. É vendo e ouvindo que desenvolvemos todas as teorias. O filósofo também acredita na bondade de Deus que tudo criou para que o homem desenvolvesse sua inteligência por meios adequados e sabedoria adquirida. E é através disso que vemos o quanto a tecnologia avançou nos tempos atuais em que o conforto está em toda parte, sendo para acender uma lâmpada ou para cozinhar o alimento.

Locke segue a tradição do só crê no valor do conhecimento do particular e na separação entre fé e razão. É sensualista, uma vez que crê que todos os conhecimentos nos vêm pelas sensações. Ele mistura um pouco da filosofia de Bacon e de Descartes, já que muitas vezes recorre ao valor da experimentação e do conhecimento matemático. Entretanto, Locke é um religioso sincero, e seu Ensaio sobre o Entendimento Humano está cheio de referências a Deus e à Sua bondade (PIMENTA, 2013).

A crença no valor do conhecimento para garantir melhores entendimentos do que é o ser humano faz com que percebemos como é trabalhoso e grandioso entender. 


\section{Conclusão}

O próprio autor já nos mostra que com seu grande conhecimento, o homem poderá avançar mais e mais para o que é necessário, é necessário apenas o compreender e aceitar o outro na sua forma de pensar, vestir, falar. O autor além de defender o conhecimento como da política, que é uma das maiores causas que ele lutou e que até hoje é respeitado por seu ponto vista e pela luta da causa dos escravos. E essa foi a grande contribuição para que pudesse compreender que além de existir as diferenças o respeito é fundamental para que todos os povos possam conviver e por isso suas obras são de grande valor até nos dias atuais.

\section{REFERÊNCIAS}

BERTUCCI, Janete Lara de Oliveira. Metodologia Básica para Elaboração de Trabalhos de Conclusão de Cursos. 1 ed. São Paulo: Atlas, 2012.

PIMENTA, Felipe. Entendimento Humano. Santa Catarina, 2013.

RODRIGUEZ, Ricardo Velez. Síntese entre empirismo e liberalismo. São Paulo, 2010. 